\author{
Anna Protasiewicz \\ Faculty of Economics and Finance \\ University of Bialystok \\ e-mail: a.protasiewicz@uwb.edu.pl \\ ORCID: 0000-0003-2256-8273
}

\title{
IMPLICATIONS OF THE COVID-19 CRISIS ON THE CREATION OF INNOVATIONS - ASSESSMENT ATTEMPT
}

\begin{abstract}
The aim of the article is an attempt to analyze the impact of the pandemic crisis (caused by the COVID-19 coronavirus) on innovations created by economic entities. The ongoing economic downturn has reasons different from previous economic peturbations, and has much more extensive effects across the entire global economy. Hence the need to analyze not individual economies as trends (megatrends) in the emergence of innovations initiated or significantly accelerated by the pandemic crisis. The analysis was made on the basis of reports from institutions such as the World Economic Forum, OECD or ESPAS, as well as preliminary studies conducted in some countries (eg the USA). It should be emphasized that due to the ongoing perturbations and the pandemic not ending, precise research results will be possible to obtain in later years.

Keywords: innovation, innovative activity, financial crisis, COVID-19 crisis, innovation trends.
\end{abstract}

\section{Introduction}

Innovation is a new solution in any field of activity, the implementation of which is related to achieving positive economic benefits, for example through an improved satisfaction of needs and/or more effective use of resources (Niedzielski, Rychlik, 2007, p. 23). Oslo Manual presented innovation as a new or improved product or process (or their combination) that differs significantly from the firm's previous products or processes and that has been made available to potential users (product) or brought into use by the unit (process) (OECD, 2018, p. 32). Alternatively, business innovation is a new or improved business product or process (or their combination), which differs significantly from the entity's previous business products or processes, that has been introduced into the market or has been brought into use by the firm. A business process innovation is a new or re-engineered business process for one or more business functions that differs significantly 
from the firm's previous processes and has been brought into use by the firm (OECD, 2018, p. 68-69). The innovativeness of an organization is the ability to absorb, i.e. constantly seek, implement and disseminate innovations. It is treated as one of the most important features of the enterprise, having a key impact on its competitiveness, and thus its market position. What is important is the application of the ideas created and the dynamics of changes introduced in the process of commercialization of innovations (Barańska-Fischer, Blażlak, 2016, p. 10).

Each innovation has its source, that is a place where a new idea has been developed contributing to the creation of such innovation. That is related both to the external environment, whose constant analysis allows for introducing changes and adjusting them to the needs of the surrounding environment and is related to the company itself by analysing its available resources (Protasiewicz, 2020, p. 82-83).

The external environment of an enterprise influences its ability to create innovations, creates favorable or difficult conditions for both the process of creating and then commercializing innovative solutions. The current economic and social situation provides entities with many challenges, which may be, on the one hand, an opportunity to increase efficiency (e.g. by increasing sales or accompanying services), and, on the other hand, an obstacle in running a business. The period of the coronavirus pandemic (COVID19 ) in $2020 / 2021$ shows that despite the extremely difficult economic situation, it is also a kind of opportunity to accelerate some positive phenomena in the area of innovation, as well as the emergence of new solutions.

In December 2019, the World Health Organization (WHO) recorded cases in the Chinese province of Wuhan, which turned out to be caused by a rapidly spreading type of coronovirus (COVID-19). The authorities of individual countries have started a policy of protection of residents, involving, inter alia, on travel restrictions, however, a global illness soon led to a declaration of a pandemic (Alexander, Jaffer, 2021, p. 17). By end of July 2021, the virus had infected over 202 million individuals and killed over 4,2 million worldwide (WHO, https://covid19.who.int/.) ${ }^{1}$.

\section{The impact of economic crises on the innovative activity of enterprises}

J.A. Schumpeter wrote that the process of industrial change is constantly revolutionizing the economic structure from within, destroying the old and creating a new one. This process was to be creative destruction 
(also known as the whirlwind of creative destruction), which was an essential fact of the capitalist economy (Stępnicka, 2013, pp. 28-29). Creative destruction prompts producers to introduce new products, new technologies and other combinations of production factors to the market, which on the one hand is accompanied by the emergence and development of new branches, and on the other hand, the destruction of existing products, enterprises and old branches of production. As a result, the functioning of the market depends on the innovations introduced by competing companies (Stępnicka, 2012, p. 219). When the economy is in a recession, the environment for doing business deteriorates significantly and financial constraints arise. At the same time, a problem in the field of human capital (brain drain) is noticed, as educated specialists decide to move abroad to search of higher wages (Caloghirou et al., 2021, p. 3).

In 2008-2010, during the last global financial crisis, many countries recorded falls in GDP, a decline in industrial production and trade, and an increase in unemployment. According to OECD research (OECD, 2012, p. 22-24), companies from Europe and the United States, which invested heavily in research and development, relatively quickly improved the level of sales of their products.

Innovations, especially in times of crisis, become the driving force of the economy and an important modernization factor, thus building the foundations for sustainable economic growth. Despite the crisis in 2008, most European countries recorded an increase in the innovative potential of their economies. Innovations also allow to obtain a competitive advantage, which applies to both the micro-, meso- and macroeconomic dimensions. The appearance of a crisis often means that companies reduce financial resources for investments, as well as for research and development. Creating innovative solutions or developing long-term strategies is often a secondary goal at this time. It is worth emphasizing, however, that innovative entities are less affected by the negative consequences of the recession and are characterized by a higher pace of development, as exemplified by Apple. In 2008, the company increased its sales by almost a half (with a drop in US GDP by $0.3 \%$ ), while in 2009 its revenues increased by over $14 \%$ (with a decline in US GDP by 3.5\%) (Ayming, 2020, p. 8).

The financial crisis of 2008-2010 caused a reduction in demand, reduced liquidity of the financial sector or increased uncertainty about future development, but at the same time initiated changes in the innovation policy. The cyclical nature of $R \& D$ expenditure and the creation of innovation has been observed in many economies in a different way. The biggest negative effects affected European countries (Iceland, Ireland, Italy) and Mexico. Some 


\section{Anna Protasiewicz}

of the economies, e.g. the BRIC group (Brazil, Russia, India and China), but also Argentina, Colombia and South Korea continued to grow. The innovation systems of these economies were less vulnerable to peturbations in financial markets. To sum up, the effects of the financial crisis or, more broadly, the economic crisis of 2008-2010 were twofold. On the one hand, it was a negative impact, related to, inter alia, with limiting the creation of innovation, the creation of new entities, venture capital financing, as well as the amount of funds (including public funds) allocated to research and development. Examples of such economies were Greece and Spain. On the other hand (after a temporary collapse), however, peturbations led to a reconstruction of the global economy, which relies more on innovative entities more resistant to future crises, and countries such as China and South Korea have done the best (OECD, 2012, pp. 24-25).

World R\&D expenditures is growing even in economies that have been hit hard by the global crisis. This is due to the strategies of companies that prioritize innovation and the competitive situation that forces the constant introduction of new products to the market. Some companies use the crisis to increase their market share through innovation or simply to conduct research at lower cost.

\section{The nature of the COVID-19 crisis}

According to the theory of the business cycle, a crisis following periods of prosperity is an inevitable event. What is surprising in the pandemic crisis (the COVID-19 crisis), compared to the one in 2008-2010, is its causes, as well as the unpredictability or the extent of its effects. This situation was (is) according to the theory of N.N. Taleb, a kind of Black Swan, and therefore an unpredictable and irregular event of enormous scale and wide-ranging consequences, unexpected for a given observer - usually called a turkey - if they not only surprise him, but also harm him (Taleb, 2013, p. 6). The pandemic crisis turned out to be a Black Swan because of its serious consequences, which were related to health and life and the inability to contain its spread (Wnorowski, Niklińska, 2020, p. 5).

The COVID-19 crisis differs from the previous collapse, including external shock affecting mainly market dynamics through a decline in demand. The direct supply-side effects of the 2008 crisis were mainly confined to the financial and banking sectors. The disruptions at the industrial level were a consequence of the progressive recession rather than of the crisis itself. There was an economic shock that affected the economic system, but to 
a limited extent. In turn, a pandemic crisis differs in the scope of its consequences (physical and mental health, economic welfare, social changes), as well as in its geographical scope (global nature). Therefore, its impact on innovation or innovativeness is different - the importance of technology or technical and scientific knowledge is emphasized, as well as difficulties in accessing resources on a global scale. Both the virus itself and lockdowns ${ }^{2}$ initiated to slow its spread, make it difficult to meet basic human needs (Dahlke et al., 2021, p. 3).

The pandemic crisis did not affect all entities in the same way - we are talking about countries, industries and enterprises. On the one hand, the consequences of the outbreak of the pandemic differed in different economies of the world in terms of the number of infections in relation to the number of people and the way in which the situation was dealt with. Countries often applied different lockdown policies, which had an impact on the economic situation. The sectors that were particularly affected were: tourism, hotel industry, gastronomy, trade and entertainment and culture industry.

Due to the COVID-19 crisis, many entrepreneurs were forced to verify their plans and minimize expenses, including those related to R\&D. However, there are a number of actions that have been taken by entities to take advantage of the station, and often to increase profits as well. The COVID19 pandemic has already forced enterprises to digitally transform - for many companies, focusing on innovation may turn out to be one of the most effective exit strategies from the crisis. Companies respond to emerging challenges by accelerating digitization, changing corporate practices or developing cost-effective solutions. It particularly emphasizes the importance of open innovation: scientists, the pharmaceutical industry, governmental and non-governmental institutions, communities and individuals should collectively accelerate the creation, deployment and testing of possible solutions and ultimately tackle the pandemic. Strategic collaboration with competitors can also contribute effectively to global pandemic mitigation efforts through the sharing of resources and capabilities. These studies suggest that crises can increase the needs of businesses and entrepreneurs for economic livelihood, collaboration and creativity; they also make an important contribution to understanding innovation processes at company level during crises (Dahlke et al., 2021, p. 2).

The pandemic crisis has resulted in wide transformations in the global market, also in terms of innovative activities. Innovation is often analyzed in terms of costs, and the question ofwhether to "make or buy" often rests on which approach costs less. But in a pandemic, time is so valuable and 


\section{Anna Protasiewicz}

essential, that the question ofcosts is far less important than the ability to get to a solution sooner (Chesbrough, 2020, p. 410). On the one hand, this leads to the emergence of completely new directions of changes, and on the other hand, accelerates the implementation of trends that have already been observed and forecasted in the future.

\section{The impact of the COVID-19 crisis on the creation of innovative solutions}

P.F. Drucker stated that the stimulus for innovation does not have to be a technological factor. This role may be played by the observation of the market and changes that take place in the sphere of consumption. Thus, the source of innovation may be: social attitudes, consumer behavior, consumer behavior trends, changes in their needs (Drucker, 1992, p. 43). The theory of absorptive capacity indicates that the emergence of innovation is based on external (related to technology) and internal (related to organization) conditions. An enterprise's innovativeness is determined by its ability to recognize the value of external information and use it in innovative activities. The information flow channel between the environment and the enterprise determines its absorption capacity (Cohen, Lewinthal, 1990, p. 128).

Research on new trends in consumer behavior seems to be particularly important in the process of creating innovation. They are conducted by trend sociologists and concern the analysis of the behavior of target groups and consumers-trendsetters, who play an opinion-forming role and create consumption patterns that are subject to imitation. This allows for forecasting and identifying future preferences and the direction of development of the needs of the general public. Thus, it enables the design of new products corresponding to the market needs and, consequently, to stay ahead of the competition, although they are accompanied by a certain risk resulting from the sensitivity of trends to changes in the economic macro environment. Therefore, there is a risk of shaping the innovation policy in line with the forecasted trends, which will quickly become obsolete (Karpińska, Matel, Protasiewicz, 2017, p. 82).

The trend can be analyzed in relation to social sciences and in relation to the theory of consumer behavior. It is a kind of prediction, assuming something that will happen and will be accepted by the statistical human/consumer (Vejlgaard, 2008, p. 26). This means a certain direction of changes in consumer behavior, lifestyle and purchasing decisions, i.e. a devel- 
opment tendency that arises as a result of the impact of a number of factors on consumers, which will most likely extend to wider groups of recipients. Megatrend, on the other hand, means such a trend that includes a long impact, going beyond one area of life and one geographical area (Kucharska, 2014, p. 220). The coronavirus pandemic undoubtedly had a huge impact on consumer behavior: changing them, but also accelerating certain expected trends that innovative companies use in their activities. The unexpected global pandemic caused by the COVID-19 virus pushed many organizations (e.g. private and public R\&D laboratories, companies and universities) to fastly obtain results for promising innovative solutions, both medical and non-medical (Dosi, Cocchi, Vignoli, 2021, p. 2979).

Highlighted in the literature and reports of international institutions (including the OECD and World Economic Forum) as a technological trend in the first decades of the 21st century. The first is problem of aging society. Extending the lives of people that matter with numerous benefits in terms of handling, especially due to the conditions of the pandemic, has gained importance (WEF, 2016, pp. 8-9):

- Healthy ageing - social connectivity and emotional health (sense of purpose, meaning in life, emotional contact and overall mental well-being). Technologies to support social participation may include social media or virtual communities, real-time videoconferencing, interactive games, social support networks or blogging platforms. Innovations for employment or volunteer opportunities include professional development and training options, online job and volunteer boards, professional networking and remote working sites, as well as industry, salary and employer quality-review sites;

- Cognitive ability - mental well-being, alcohol intake, nutrition and medication adherence;

- Physical ability - mobility, musculoskeletal disorders and mental wellbeing (dementia, cognitive decline). Technologies that encourage the measurement of regular balance and aerobic training promote physical ability in older life.

It should be emphasized that the solutions that were to be used by elderly people, in conditions of isolation, were applicable to everyone. Therefore, various platforms and applications have developed to improve people's lives in terms of caring for physical and mental health (telemedicine, diagnoses or prescriptions via the Internet, psychological advice), educational classes and online courses or social media involving participants in contacts that in the real world were limited. eHealth functions of telemedicine and mHealth have been developed or appropriated further during the pandemic, 


\section{Anna Protasiewicz}

practiced as they are through 'mobile devices, such as mobile phones, patient monitoring devices or personal digital assistants. These forms are taking advantage of the growing number of individuals with access to mobile phones and the internet to spread relevant health information and services (Fejerskov, Fetterer, 2020, p. 12). Establishing the core of the trends also highlights that COVID-19 innovation is happening at the intersection of health, data, urbanization, connected worlds, offline and simultaneously online, and commerce (Ebersberger, Kuckertz, 2021, p. 132).

It's connected with technological innovation as a meta-trend - it permeates virtually all other aspects of human life. Technological progress is a constant development, but nowadays the intelligence of machines is starting to compete with human intelligence. This will happen in the coming years as innovations are expected in particular regarding the Internet of Things, artificial intelligence, advanced robotics, wearables and 3D printing, as well as blockchain, new energy storage methods and 5G. These innovations will make everyday life easier, but they represent economic and employment potential (e.g. by changing the labor market). Machines are likely to replace people in areas that are repetitive and mechanical (drivers or telephone operators) rather than taking over entire labor markets as new professions or positions emerge (ESPAS, 2019, p. 28).

The World Economic Forum presents 6 megatrends concerning software and services (WEF, 2015, p. 5):

- people and the internet - development of methods of constant communication between people and obtaining information, wearable and implantable technologies will enhance people's "digital presence" (electronic wristbands/watches, locators, etc.);

- computing, communications and storage everywhere - decrease in the size and cost of computing and connectivity technologies, which allows access to almost unlimited memory capacity (virtual disks);

- the Internet of Things Smaller - public sensors - in homes, clothes and accessories, cities, transport and energy networks, and production processes;

- Artificial intelligence (AI) and big data - creating more data and the ability for software to learn and evolve itself, is advancing rapidly;

- the sharing economy and distributed trust - the internet is driving a shift towards platform-based social and economic networks and models;

- the digitization of matter - physical objects are created using additive or 3D printing, a process that transforms industrial production, allowing products to be printed at home. 
Recovering from Covid-19 will soon test economic systems and innovation will have an important role to play in recovering from the aftermath of the coronavirus. Table 1. shows the impact on society of technological developments during the COVID-19 crisis. H. Chesbrough argues that the point is that innovation in overcoming innovation that now has a competitive advantage (Open innovation), focusing on becoming and step by step to achieve successes and solutions. An example of such an activity is social organizations and pharmaceutical companies that have various universal vaccinations against the virus (Chesbrough, 2020, p. 410).

Table 1

The impact on society of technological developments during the COVID-19 crisis

\begin{tabular}{|l|l|l|}
\hline \multicolumn{1}{|c|}{ Technological development } & \multicolumn{1}{|c|}{ Innovation logic } & \multicolumn{1}{c|}{ Social impact } \\
\hline Ventilators, vaccines & Time-to-market & Crisis readiness \\
\hline $\begin{array}{l}\text { Artificial intelligence, } \\
\text { ventilators }\end{array}$ & Cross-sectoral innovation & Innovation in ecosystems \\
\hline Respirators, sanitizers & $\begin{array}{l}\text { Flexible manufacturing } \\
\text { systems }\end{array}$ & Social responsibility \\
\hline Artificial intelligence, robotics & Big data & Intellectual property \\
\hline $\begin{array}{l}\text { Wearables, cashless payment, } \\
\text { streaming, e-commerce }\end{array}$ & Technology acceptance & Citizen surveillance \\
\hline $\begin{array}{l}\text { Videoconferencing, e-learning, } \\
\text { e-gaming }\end{array}$ & Digitization & Flexible work methods \\
\hline
\end{tabular}

Source: (Brem, Viardot, Nylund, 2021, p. 5)

The COVID-19 megatrends focus on health and the flow of information (e.g. real-time information for people on COVID-19 issues, government restrictions). The activity of the state only strengthened the trends related to remote work or the organization of people's lives by means of various applications and services (online shopping, instant messaging), also strongly referring to the urbanization megatrend. Innovation seems to be possible thanks to technology-based megatrends that support artificial intelligence innovative COVID-19 solutions related to health, work and consumption, the use of big data and network technologies (Ebersberger, Kuckertz, 2021, p. 130).

The COVID-19 crisis has accelerated trends already underway in STI (Science, Technology and Innovation). It has further opened access to data and publications, increased the use of digital tools, enhanced international collaboration, spurred a variety of public-private partnerships, and encour- 
aged the active engagement of new players. The effects of the pandemic, in particular the blockades, also disrupted operations innovation systems that threaten key production and innovation capacities, especially in the hardest-hit sectors. Business investment in research and innovation is procyclical and therefore vulnerable to reduce in times of crisis. This crisis may be different as some of the world's leading R\&D players expand their activities in times of crisis. The pandemic could aggravate existing gaps in R\&D between 'lead' and 'lagging' sectors, large and small firms, and individual economies. This uneven distribution can widen the productivity gap and deepen vulnerability marauders and diminishing economic resilience (OECD, 2021, p. 13).

\section{Conclusions}

Research and innovation systems impressive responded to the pandemic: private and public entities provided emergency solutions (vaccines), but also implemented digital technologies that helped reduce the impact of the pandemic. COVID-19 has accelerated the trends that have already emerged, opening up access to scientific publications or increasing the use of tools. However, the STI (Science, Technology and Innovation) system has had a negative impact on the participation of small and medium-sized enterprises (SMEs), early-stage start-ups and young researchers. In the short term, governments should continue to support research and innovation efforts to find solutions to the pandemic and mitigate its negative effects (OECD, 2021, p. 16).

Due to the multifaceted nature of the pandemic crisis, the following conclusions about innovation can be drawn:

- crisis driven innovation responds to a wide variety of people's needs;

- the diversity of needs drives the emergence of new fields, and hence innovative solutions related to tchem;

- innovations created during the crisis respond to the changing needs of people as a result;

- big shifts in technology are achieved in days not in years;

- pandemic crisis accelerated the trends that have already emerged such as digitalization, solutions for health, big data.

Many of the advances that have been made in the pandemic of improving productivity, efficiency and even creativity (automation and artificial intelligence, data control, cities). Savings thanks to them, the resulting costs and costs of production occurred in an economy based on innovation, ideas 
and information, not on time and male maintenance. Information and data a new currency that a large company is increasingly checking a fixed place in order to get value.

\section{N O T E S}

1 World Health Organization, WHO Coronavirus Disease (COVID-19) Dashboard (August 9, 2021), reporting 202608306 cases of COVID-19 worldwide and 4293591 deaths, https://covid19.who.int/.

2 State tools aimed at limiting the spread of the virus: closing schools or institutions, dining and commercial establishments, restricting travel and crowds, etc.

\section{R E F E R E N C E S}

Alexander, K., Jaffer, J. (2021). COVID-19 and the Cyber Challenge. The Cyber Defense Review, 6(2).

Barańska-Fischer, M., Blażlak, R. (2016). Innowacyjność organizacji - istota zagadnienia, uwarunkowania i charakter, [in:] Barańska-Fischer, M. (Ed.), Blażlak, R., Szymański, G., Innowacje w biznesie. Wybrane zagadnienia, Monografie Politechniki Łódzkiej, Łódź.

Bieliński, T. (2010). Innowacje przedsiębiorstw na świecie w okresie kryzysu, [in:] P. Antonowicz (ed.), Innowacyjne strategie kreowania przewagi konkurencyjnej przedsiębiorstw, Fundacja Rozwoju Uniwersytetu Gdańskiego, Gdańsk.

Brem, A., Viardot E., Nylund P.A. (2021). Implications of the coronavirus (COVID19) outbreak for innovation: Which technologies will improve our lives?, Technological Forecasting and Social Change, 163, https://doi.org/10.1016/ j.techfore.2020.120451.

Caloghirou, Y., Giotopoulos, I., Kontolaimou, A., Korra, E., Tsakanikas, A. (2021). Industry-university knowledge flows and product innovation: How do knowledge stocks and crisis matter?, Research Policy, Volume 50, Issue 3. https:// doi.org/10.1016/j.respol.2020.104195.

Chesbrough, H. (2020). To recover faster from Covid-19, open up: Managerial implications from an open innovation perspective, Industrial Marketing Management, 88, https://doi.org/10.1016/j.indmarman.2020.04.010.

Cohen, W.M., Lewinthal, D.A. (1990). Absorptive capacity: A new perspective on learning and innovation, Administrative Science Quarterly, 35.

Dahlke, J., Bogner, K., Becker, M., Schlaile, M.P., Pyka, A., Ebersberger, B. (2021). Crisis-driven innovation and fundamental human needs: A typological framework of rapid-response COVID-19 innovations, Technological Forecasting and Social Change, 169, https://doi.org/10.1016/j.techfore.2021.120799. 
Dosi, C., Cocchi, N., Vignoli, M. (2021). Ten transform emergency now! - Facing COVID 19 with open and frugal innovation, Proceedings of the Design Society, 1, 2971-2980. doi: 10.1017/pds.2021.558.

Droga do innowacji a COVID-19. Wyzwania dla CEO. Raport 2020 (2020), Ayming, https://www.ayming.pl/wp-content/uploads/sites/16/2020/06/ Droga-do-innowacji.-Wyzwania-CEO_raport.pdf

Ebersberger, B., Kuckertz, A. (2021). Hop to it! The impact of organization type on innovation response time to the COVID-19 crisis, Journal of Business Research, 124, https://doi.org/10.1016/j.jbusres.2020.11.051.

Fejerskov, A.M., Fetterer, D. (2020). Innovatice responses to COVID-19: Future pathways for 'techvelopment' and innovation, Danish Institute for International Studies, Copenhagen.

Karpińska, K., Matel, A., Protasiewicz, A. (2017). Konsument $w$ działalności organizacyjnej przedsiębiorstw, Polskie Towarzystwo Ekonomiczne Oddział w Białymstoku, Białystok.

Kucharska, B. (2014). Trendy w zachowaniach konsumentów jako uwarunkowanie innowacji w handlu zagranicznym, Zeszyty Naukowe Uniwersytetu Ekonomicznego w Katowicach. Studia Ekonomiczne, 187.

Niedzielski, P., Rychlik, K. (2007). Kreatywność a rozwój technologii informacyjnych - nowe obszary innowacyjności, Zarzadzanie Zasobami Ludzkimi, 1.

OECD (2021). OECD Science, Technology and Innovation Outlook 2021: Times of Crisis and Opportunity, OECD Publishing, Paris, https://doi.org/10.1787/ 75f79015-en

OECD (2018). Oslo Manual: Guidelines for Collecting, Reporting and Using Data on Innovation, Paris-Luxembourg, DOI: 10.1787/9789264304604-en.

OECD (2012), OECD Science, Technology and Industry Outlook 2012, OECD Publishing. http://dx.doi.org/10.1787/sti_outlook-2012-en.

Protasiewicz, A. (2020). Innovativeness of enterprises in Poland and their capacity to absorb innovation, Optimum. Economic Studies, 2(100), DOI: 10.15290/oes.2020.02.100.06.

Stępnicka, N. (2013). Koncepcja twórczej destrukcji J.A. Schumpetera a wyzwania współczesnej gospodarki, Studia Ekonomiczne, Uniwersytet Ekonomiczny w Katowicach, 129 Wspólczesne problemy ekonomiczne: wybrane zagadnienia teoretyczne a praktyka gospodarcza.

Stępnicka, N. (2012). Koncepcja twórczej destrukcji J.A. Schumpetera a rozwój przedsiębiorstw w regionie, Ekonomia i Prawo. 11. 10.12775/EiP.2012.043.

Taleb, N.N. (2013). Antykruchość. O rzeczach, którym służa wstrząsy, Kurhaus Publishing.

The European Strategy and Policy Analysis System (ESPAS) (2019), Global Trends to 2030: Challenges and Choices for Europe, https://www.iss.europa.eu/ sites/default/files/EUISSFiles/ESPAS_Report.pdf 
Implications of the COVID-19 Crisis on the Creation of Innovations...

Vejlgaard, H. (2008). Anatomia trendu, Oficyna a Wolters Kluwer Business, Kraków.

World Economic Forum's Global Agenda Council on the Future of Software \& Society (WEF) (2015), Deep Shift Technology Tipping Points and Societal Impact, Survey Report, http://www3.weforum.org/docs/WEF_GAC15_Techno logical_Tipping_Points_report_2015.pdf

World Health Organization, WHO Coronavirus Disease (COVID-19) Dashboard (August 9, 2021), reporting 202608306 cases of COVID-19 worldwide and 4293591 deaths, https://covid19.who.int/.

Wnorowski, H., Niklińska, N. (2020). Coronaeconomy the beginning of new normality? - in search of a new conceptual order, Optimum. Economic Studies, 2(100), DOI: 10.15290/oes.2020.02.100.01. 